\title{
CEREBRO-SPINAL FEVER
}

by

MICHAEL FOSTER, M.A., M.D.

Captain Royal Army Medical Corps, Territorial Force

and

J. F. GASKELL, M.A., M.D.

Captain Royal Army Medical Corps, Territorial Force

Large royal 8vo. pp. $x+222$. With 11 plates, 5 charts, and 3 text-figures. Price $12 \mathrm{~s} 6 \mathrm{~d}$ net

"As a reault of their experience with cerebro-8pinal fever during 1915 at the lat Eastern General Hospital, Captains Michael Foster and J. F. Gaskell have written an excellent practioal account of the disease, its pathology, bacteriology, and management,....

The book is excellently arranged, well written, and full of practical details that make it invaluable for the medieal man and laboratory workers who have to deal with cases of cerebro. spinal fever. It may be most warmily rocommended to their attention."-British Mcdical Journal

"The book is far from being a mere compilation; it contains the record of much original and valuable work and thought, and must be referred to by other inveetigators upon cerebro-spinal fever.

The illustrations are excellent, and, what is more, fill a distinct want. To our knowledge no such full series of reproductions of the rashes of 'spotted fever' has hitherto been published."

The Cambridge Reviev.

Cambridge University Press

C. F. Clay, Manager: Fetter Lane, London

\section{THE JOURNAL OF ZOOLOGICAL RESEARCH}

(Founded 1905 as "The Journal of Economic Blology")

Edited by

WALTER E. COLLINGE,

D.Se. (Bt And.), M.Se. (Birm.), F.L.S., ete., Research Fellow of the University of St Andrews.

A quarterly periodical for the publication of records of original research in systematic and structural zoology.

Fully illustrated by lithographio plates and text-figures.

Each volume will consist of four parts, price $21 s$.

All editorial communications should be addressed to

Dr Walter E. ColnnveE, the University, St Andrews

and all subscriptions to

London: Dulau \& Co., Litd., 37, Soho Square, W. 


\section{CONTENTS}

(All vights reserved)

Megarti, F. J. A Tri-Radiate Tapeworm (Anoplocephala perfoliata Goeze) from the Horse. (With Plate XVIII and 2 Text-figures)

MEgarT, F. J. A Contribution to the Knowledge of the Tapeworms of Fowls and of Sparrows. (With Plates XIX-XXI and 1 Text-figure).

Baysis, H. A. The Types of the Species of Ascaris described by Baird. (With 3 Text-figures) . . . . .

Boulnnger, Charles L. Solerostome Parasites of the Horse in England. I. The Genera Triodontophorus and Oesophagodontus. (With Plate XXII and 7 Text-figures). .

GraHaM-SMTth, G. S. Observations on the Habits and Parasites of Common Flies. (With Plates XXIII-XXX, 17 Text-figures and 9 Charts).

INDEX OF AUTHORS

INDEX OF SUBJECTS

PARASITOLOGY is published about four times a year. The numbers afterwards are issued in volumes each containing four numbers and amounting to between 400 and 500 pages, with plates and figures.

Papers for publication should be sent to Professor Geo. H. F. NutraLL, F.R.S., Longfield, Madingley Road, Cambridge. Other communications should be addressed to the University Press, Cambridge.

Papers forwarded to the Editors for publication are understood to be offered to PARASITOLOGY alone, unless the contrary is stated.

Contributors reeeive seventy-five copies of their papers free. Additional copies, not exceeding 200 , may be had at cost price: these should be ordered when the final proof is returned.

The subscription price is $£ 1$. 108 . per volume (post-free), payable in advance; single numbers 108 . net (double number 20 s. net). Subscribers to the Journal of Hygiene may obtain single numbers of PARASITOLOGY at the reduced price of $78.6 d$, net, or may become subseribers at the reduced rate of $£ 1$. 1s. per volume. Subscriptions may be sent to any Bookseller, or to Mr C. F. CLAY, Manager, Cambridge University Press, Fetter Lane, London, E.C.

The Cambridge University Press has appointed the University of Chicago Press agents for the sale of Parasitology in the United States of America and has authorised them to charge the following prices: Subseription $\$ 7.50$ net per volume; single numbers $\$ 2.50$ net each, double numbers $\$ 5.00$ net each. Subseribers to the Journal of Hygiene may become subseribers to Parasitology at the reduced rate of $\$ 5.25$ per volume.

The prices of back volumes are as follows:

Volumes I, II, III and IV (1908-11). Each volume in four parts, paper covers, 21s, net per volume. Bound in buckram, 25s. net per volume.

Volumes V, VI, VII and VIII (1912-16). Each volume in four parts, paper covers, 308 . net per volume. Bound in buckram, 34s, 6d. net per volume, 